The

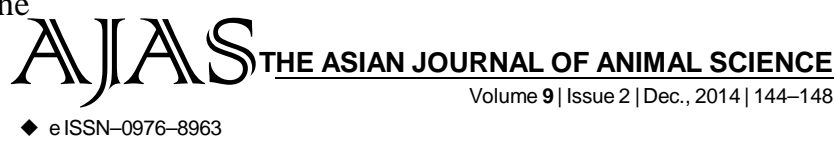

DOI : 10.15740/HAS/TAJAS/9.2/144-148 Visit us | www.researchjournal.co.in

RESEARCH ARTICLE........

\title{
Effect of dried tuna waste silage on blood biochemical profile in large white yorkshire pigs
}

K.S. ANURAJ, K. SHYAMA AND M. SREEPARVATHY

\begin{abstract}
An investigation was carried out for a period of 104 days on thirty six weaned Large White Yorkshire piglets to find out the effect of dietary incorporation of dried tuna waste silage on blood biochemical parameters. Dried tuna waste silage was used to replace dried fish on protein basis at 0,50 and 100 per cent, in isocaloric and isonitrogenous grower and finisher rations as dietary treatments $\mathrm{T}_{1}$, $\mathrm{T}_{2}$ and $\mathrm{T}_{3}$, respectively. All the animals were maintained on their respective dietary regimen from weaning to an average slaughter weight of $70 \mathrm{~kg}$. Blood samples were collected at the beginning and end of the experiment and analysed for different blood parameters. Plasma mineral concentration of $\mathrm{Ca}, \mathrm{P}$,

Author for Corresponding -

K.S. ANURAJ

Division of Animal Nutrition,

$\mathrm{Mg}, \mathrm{Mn}$ and $\mathrm{Zn}$ were similar while the plasma $\mathrm{Cu}$ concentration of pigs maintained under rations $\mathrm{T}_{2}$ and $\mathrm{T}_{3}$ were significantly lower $(\mathrm{P}<0.05)$ than that of $\mathrm{T}_{1}$. Total protein and blood urea nitrogen of pigs maintained under the three dietary treatments were similar.
\end{abstract} Indian Veterinary Research Institute, Izatnagar, BAREILLY

(U.P.) INDIA

Email: anurajks@gmail.com

See end of the article for Coopted authors'
KEY WORDS....... Piglets, Dried tuna waste silage, Blood biochemical parameters

HOW TO CITE THIS ARTICLE - Anuraj, K.S., Shyama, K and Sreeparvathy, M. (2014). Effect of dried tuna waste silage on blood biochemical profile in large white yorkshire pigs. Asian J. Animal Sci., 9(2) : 144-148.

ARTICLE CHRONICLE - Received : 23.06.2014; Revised : 30.10.2014; Accepted : 15.11.2014 